\title{
Dietary fat modifies some metabolic actions of human recombinant tumour necrosis factor $\alpha$ in rats
}

\author{
BY D. C. BIBBY AND R. F. GRIMBLE* \\ Department of Human Nutrition, University of Southampton, Bassett Crescent East. \\ Southampton SO9 $3 T U$
}

(Received 30 June 1989 - Accepted 12 December 1989)

\begin{abstract}
To examine how fat might influence the metabolic effects of tumour necrosis factor $\alpha$ (TNF $\alpha$ ), human recombinant TNF $\alpha$ was given intravenously to rats that had been fed for 12 weeks on diets containing (g/kg) 200 maize oil or 190 coconut oil + 10 maize oil. Rectal temperature and tissue composition measurements were made 8 and $24 \mathrm{~h}$ after injection. Ambient temperatures of $20^{\circ}$ and $25^{\circ}$ were employed to accentuate rectal temperature changes. Doses of 30 and $300 \mu \mathrm{g} \mathrm{TNF} \alpha / \mathrm{kg}$ body-weight were given, and brought about depression of serum zinc and albumin and elevation of copper. Muscle protein content was decreased and liver protein and $\mathrm{Zn}$ content enhanced by TNF $\alpha$. Serum $\mathrm{Zn}$ and liver $\mathrm{Zn}$ content were negatively correlated $8 \mathrm{~h}$ after injections. Hypothermia developed within $1 \mathrm{~h}$ of injection. All responses except the rise in serum $\mathrm{Cu}$ and gain in liver $\mathrm{Zn}$ were more intense at the higher than at the lower dose of TNF $\alpha$. Hypothermia was exacerbated by an environmental temperature of $20^{\circ}$. The coconut-oil diet blunted the hypothermia and likewise the changes in serum albumin and $\mathrm{Cu}$ content $8 \mathrm{~h}$ after injections and in muscle and liver protein after $24 \mathrm{~h}$. Changes in eicosanoid metabolism may be involved in the modulatory effects of the coconut-oil-enriched diet.
\end{abstract}

Tumour necrosis factor $\alpha$ : Fat and tumour necrosis: Rat

Many of the responses to invasion by bacteria, viruses or parasites (Beisel, 1975) are initiated by the secretion of cytokines such as interleukin 1 (IL1) and tumour necrosis factor $\alpha(\mathrm{TNF} \alpha)$ from macrophages. The effects of IL1 and TNF $\alpha$ in vivo include fever, shock, protein loss from muscle and alterations of the pattern of protein synthesis in liver (Dinarello et al. 1986a; Dinarello, 1987). The production of acute-phase proteins is enhanced and that of serum albumin decreased (Perlmutter et al. 1986). Serum zinc concentration decreases due to uptake into liver and kidney (DiSilvestro \& Cousins, 1984 ; Cousins, 1985). Serum copper rises due to an increase in the Cu-binding protein caeruloplasmin.

Prostaglandins (PG) and possibly leukotrienes (LT) may be involved in the mode of action of endotoxin, IL1 and TNF $\alpha$ on several tissues. PG are involved in fever (Bernheim et al. 1979; Sobrado et al. 1983; Dinarello et al. 1986a, b; Revhaug et al. 1988) and the profound fall in temperature caused by large doses of TNF $\alpha$ is prevented by cyclooxygenase and 5-lipoxygenase inhibitors (Kettlehut et al. 1987; Bibby \& Grimble, 1989a). Muscle protein loss after endotoxin and IL1 injection is also blocked by cyclooxygenase inhibitors (Baracos et al. 1983; Wan \& Grimble, 1986a) and increased PGE $_{2}$ production has been demonstrated in vitro, in skeletal muscle exhibiting increased catabolism in response to IL1 (Dinarello, 1987). The decline in serum $\mathrm{Zn}$ which followed endotoxin administration is inhibited by the 5-lipoxygenase inhibitor, AA861 (Wan \& Grimble, 1986 b).

Macrophage function is sensitive to nutritional factors. Kauffman et al. (1986) and Keenan et al. (1982) demonstrated a decreased ability of macrophages from malnourished patients to produce IL1. Dietary fat affects macrophage activities such as free radical

* For reprints. 
Table 1. Composition of diets $(\mathrm{g} / \mathrm{kg})$

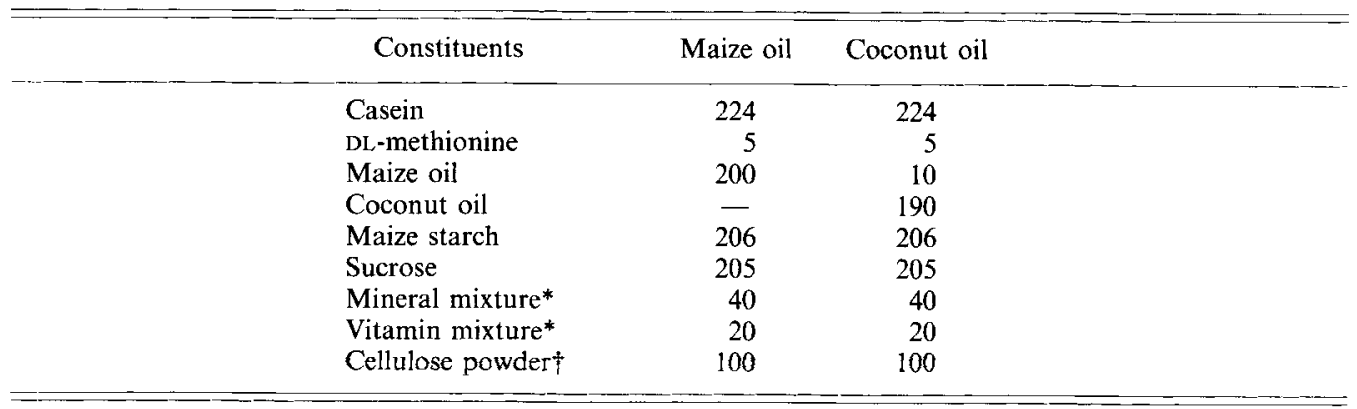

* American Institute of Nutrition (1977).

† Solkafloc BW 40; Johnson, Jorgensen and Wettre Ltd, Wokingham, Berks.

production (Johnston \& Marshall, 1984; Magrum \& Johnston, 1985). The effects of fat on cytokine production have not been studied in detail, although monocytes from volunteers fed on fish-oil supplements show a reduced ability to produce IL1 and TNF $\alpha$ in response to endotoxin (Endres et al. 1989). In a previous study, we showed that giving rats diets low in linoleate blunted many responses to Escherichia coli endotoxin. Examination of phosphatidyl choline fatty acid compositions of spleen showed decreases in the concentration of arachidonic acid and its precursor linoleic acid (Wan \& Grimble, 1987). As the former fatty acid acts as the parent compound for synthesis of the more potent forms of PG and LT (Moncada \& Vane, 1983), it is possible that diets that were low in linoleate modified the stimulatory effect of endotoxin or endogenous cytokines (or both) on eicosanoid metabolism within target tissues. It was also possible that the diet may have modified cytokine release. Thus, either cytokine production, or actions, or both may have been modified. The second of the three possibilities is examined in the present study. Changes brought about by two doses of recombinant human TNF $\propto$ over a $24 \mathrm{~h}$ time-course were studied in rats fed on diets rich and poor in linoleate content as in our earlier study (Wan \& Grimble, 1987). Maize oil was the only fat source in the former diet. The fat source in the latter diet was predominantly coconut oil with a small addition of maize oil to prevent essential fatty acid deficiency. The variables studied were: liver and muscle total protein content; serum $\mathrm{Zn}, \mathrm{Cu}$ and albumin concentrations; liver $\mathrm{Zn}$ content; and changes in body temperature.

The ability of rats to develop hypothermia was tested by keeping rats at environmental temperatures of $20^{\circ}$ or $25^{\circ}$ after saline $(9 \mathrm{~g}$ sodium chloride/1) or TNF $\alpha$ injections, since rats are less likely to develop fever in response to endotoxin at low environmental temperatures (Szekely \& Szelenyi, 1979). The short-term effects of TNF $\alpha$ on tissue composition were examined in the groups maintained at a temperature of $20^{\circ}$. The longterm effects of TNF were examined in groups maintained at $25^{\circ}$.

\section{MATERIALS AND METHODS}

\section{Animals}

Male Wistar rats ( 3 weeks old) from the Southampton University Medical School colony were fed, ad lib., on synthetic diets containing either $200 \mathrm{~g}$ maize oil $/ \mathrm{kg}$ or $190 \mathrm{~g}$ coconut oil and $10 \mathrm{~g}$ maize oil $/ \mathrm{kg}$ diet. Diet composition (Table 1) was the same as in the earlier study on the effects of endotoxin (Wan \& Grimble, 1987) and the feeding period was 12 weeks. 
FAT MODIFIES RESPONSES TO TNF $\alpha$

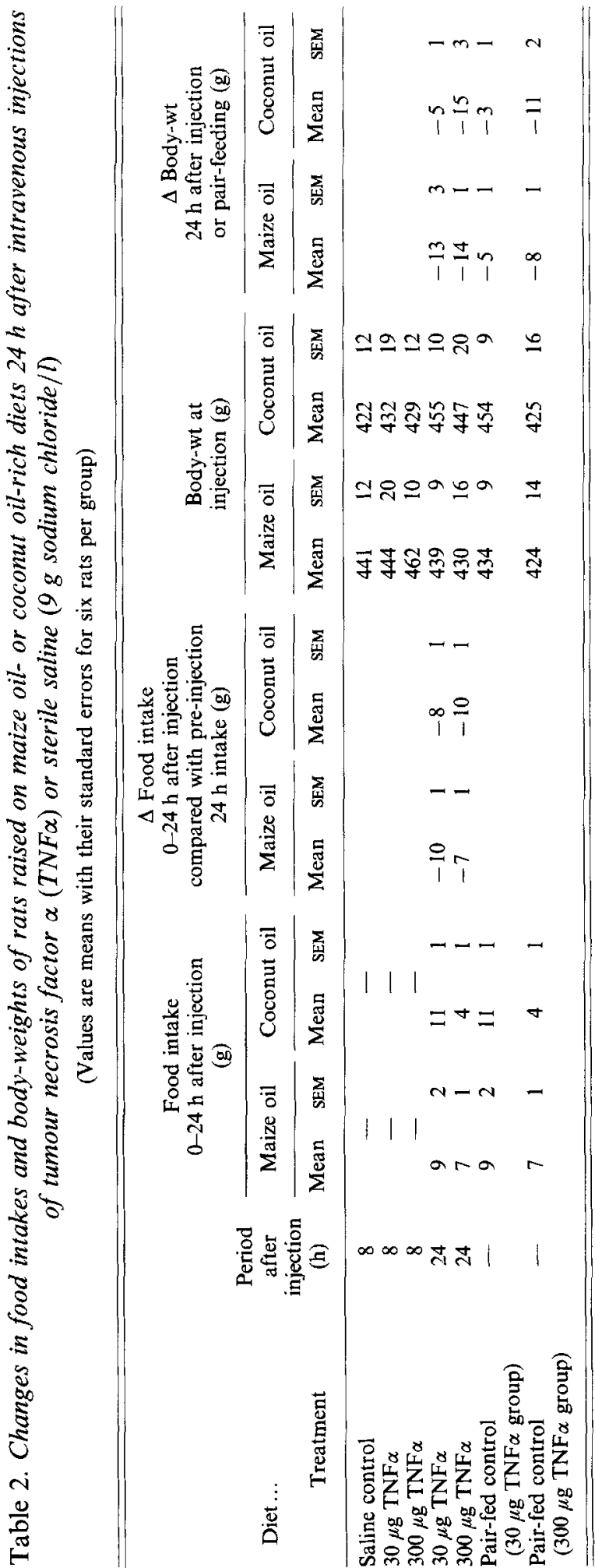




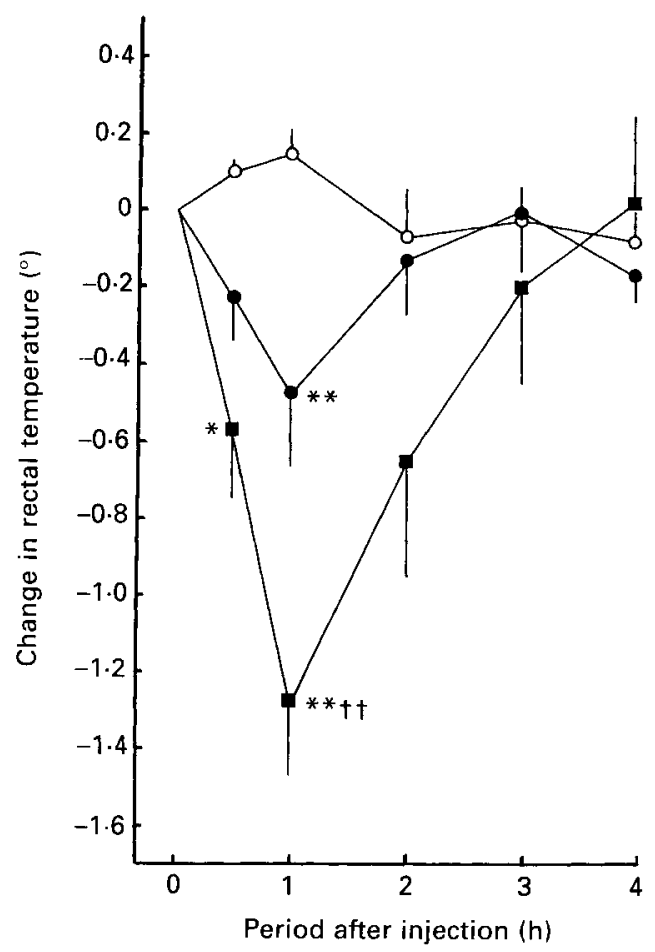

Fig. 1. Effect of intravenous injection of $30(O)$ or $300(\square) \mu \mathrm{g}$ recombinant human tumour necrosis factor $\alpha$ $(\mathrm{TNF} \alpha) / \mathrm{kg}$ body-weight, compared with sterile saline $(9 \mathrm{~g}$ sodium chloride $/ 1)(\mathrm{O})$, on rectal temperatures of rats fed from weaning for 12 weeks on a diet containing $200 \mathrm{~g}$ maize oil $/ \mathrm{kg}$. Temperatures measured at an ambient temperature of $25^{\circ}$. Values are means with their standard errors, represented by vertical bars, for groups of six rats. Values were significantly different from saline control (two-way analysis of variance): ${ }^{*} P<0 \cdot 05,{ }^{* *} P<$ $0 \cdot 01$; and different from rats given $30 \mu \mathrm{g} \mathrm{TNF} \alpha / \mathrm{kg}: \dagger+P<0 \cdot 01$.

\section{Experimental protocol}

Rats were housed in groups of three in wire cages and kept at ambient temperature of $25^{\circ}$ on a $14 \mathrm{~h} \mathrm{light-10} \mathrm{h} \mathrm{dark} \mathrm{cycle.} \mathrm{At} \mathrm{the} \mathrm{end} \mathrm{of} \mathrm{the} \mathrm{feeding} \mathrm{period} \mathrm{rats} \mathrm{were} \mathrm{randomly}$ assigned to subgroups of six rats, continuing on the same diet but being caged individually. After $3 \mathrm{~d}$, the subgroups which were to have short-term effects of TNF $\alpha$ examined, and their controls, were placed in a room at $20^{\circ}$. Care was taken to minimize the stress of this manoeuvre by leaving the animals in their own cage and by gentle handling. Recombinant human $\mathrm{TNF} \propto$ (endotoxin $<137 \mathrm{pg} / \mathrm{mg}$ protein; BASF/Knoll AG, Ludwigshaven, West Germany), or sterile non-pyrogenic saline was given via the lateral tail vein to the subgroups from each dietary treatment at both environmental temperatures. Injection volumes of $1 \mathrm{ml} / \mathrm{kg}$ were used and doses of 30 or $300 \mu \mathrm{g} \mathrm{TNF} \alpha / \mathrm{kg}$ body-weight administered. Just before injections, food was removed from all cages and rectal temperatures measured using a plastic-coated probe inserted approximately $60 \mathrm{~mm}$ into the rectum. Temperatures were measured to the nearest $0 \cdot 1^{\circ}$ with an electronic thermometer (Light and Co. Ltd, Brighton). Injections commenced at 08.00 hours and were completed by 10.00 hours. Temperatures were monitored for $4 \mathrm{~h}$. At $8 \mathrm{~h}$ after injection, half the $\mathrm{TNF} \alpha$ - and saline-treated rats from each dietary group were stunned and decapitated. Blood was collected, and liver and tibialis muscle were rapidly removed, weighed, wrapped in aluminium foil and frozen in liquid nitrogen. Food was restored to all the remaining 


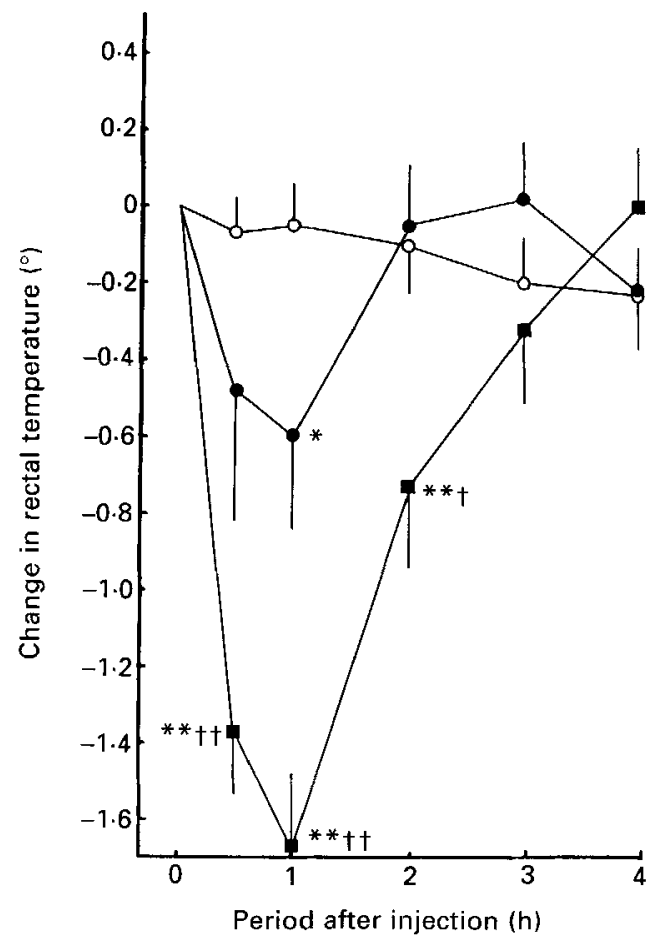

Fig. 2. Effect of intravenous injection of 30 (O) or 300 (O) $\mu \mathrm{g}$ recombinant human tumour necrosis factor $\alpha$ $(\mathrm{TNF} \alpha) / \mathrm{kg}$ body-weight, compared with sterile saline $(9 \mathrm{~g}$ sodium chloride/1) $(\mathrm{O})$, on rectal temperatures of rats fed from weaning for 12 weeks on a diet containing $200 \mathrm{~g}$ maize oil $/ \mathrm{kg}$. Temperatures measured at an ambient temperature of $20^{\circ}$. Values are means with their standard errors, represented by vertical bars, for groups of six rats. Values were significantly different from saline control (two-way analysis of variance): ${ }^{*} P<0.05,{ }^{* *} P<$ 0.01 ; and different from rats given $30 \mu \mathrm{g} \mathrm{TNF} \alpha / \mathrm{kg}: \dagger P<0.05,+\uparrow<0.01$.

animals and the remaining TNF $\alpha$-treated animals killed $24 \mathrm{~h}$ after injection and tissues collected as described earlier. As TNF $\alpha$ suppresses food intake, saline-injected pair-fed controls were prepared for each of the groups killed $24 \mathrm{~h}$ after TNF $\alpha$ injection by noting the weight of food consumed between 8 and $24 \mathrm{~h}$ after TNF $\alpha$ injection. A similar amount was given to pair-fed controls during the same period the following day. As this is normally the quiescent part of the rat's daily life-cycle they were not particularly voracious when food was re-introduced. The first $8 \mathrm{~h}$ of the day were spent without food. After the pairfeeding period rats were killed and processed exactly as the other rats in the study.

Tissues were stored at $-20^{\circ}$ until analysed. Tissue protein was measured by the Lowry technique (Lowry et al. 1951), after preparation as described by Garlick et al. (1980). Serum albumin was determined by the bromocresol green method (McPherson \& Everard, 1972) and tissue and serum $\mathrm{Zn}$ and serum $\mathrm{Cu}$ by atomic absorption spectroscopy. Tissues were prepared for $\mathrm{Zn}$ analysis as described by Tocco-Bradley \& Kluger (1984).

\section{Statistical analysis}

The values were examined by two-way analysis of variance for the effect of TNF $\alpha$, of fat, of dose of $\mathrm{TNF} \alpha$, and $\mathrm{TNF} \alpha \times$ fat and dose $\times$ fat interactions. The relationship between serum and liver $\mathrm{Zn}$ was examined by linear correlation. Mean values with their standard errors are quoted throughout. 


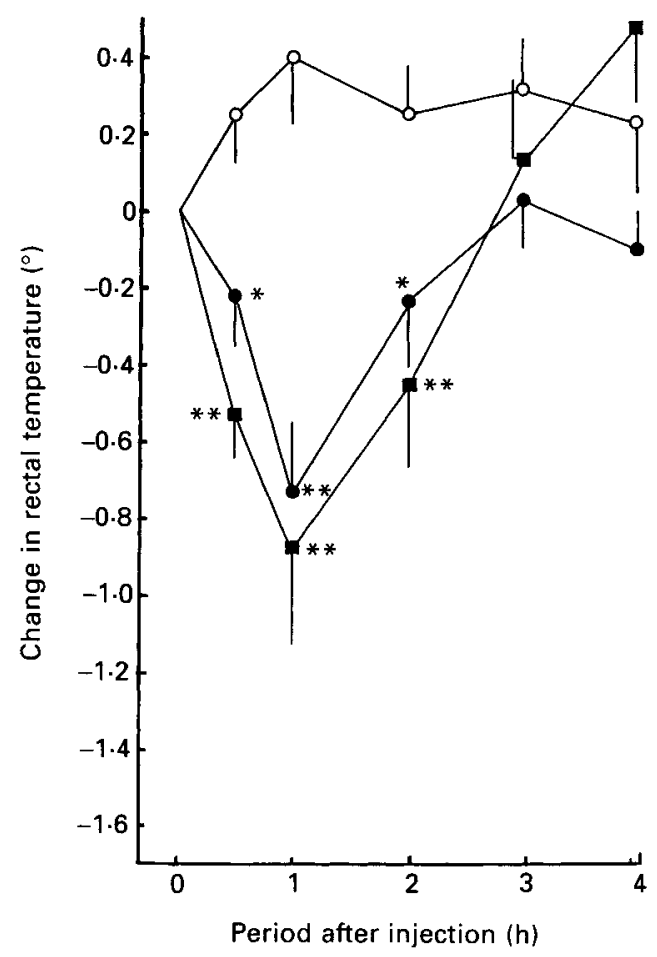

Fig. 3. Effect of intravenous injection of $30(\odot)$ or $300(\mathbb{D}) \mu \mathrm{g}$ recombinant human tumour necrosis factor $\alpha$ (TNF $\alpha) / \mathrm{kg}$ body-weight, compared with sterile saline $(9 \mathrm{~g}$ sodium chloride/l) $(O)$, on rectal temperatures of rats fed from weaning for 12 weeks on a diet containing $190 \mathrm{~g}$ coconut oil and $10 \mathrm{~g}$ maize oil $/ \mathrm{kg}$. Temperatures measured at an ambient temperature of $25^{\circ}$. Values are means with their standard errors, represented by vertical bars, for groups of six rats. Values were significantly different from saline control (two-way analysis of variance): $* P<0.05,{ }^{* *} P<0.01$.

\section{RESULTS}

The changes in food intake and body-weight following TNF $\alpha$ administration are shown in Table 2. TNF $\alpha$ resulted in reductions in appetite and loss of body-weight at both doses employed. A rapid decline in rectal temperature occurred in all animals within $30 \mathrm{~min}$ of receiving TNF $\alpha$. The decline continued until $1 \mathrm{~h}$ after injection, after which values returned towards those in the saline-treated animals as shown in Figs 1-4. The environmental temperature, type of diet and dose of $\mathrm{TNF} \alpha$ influenced the size of the reduction in temperature below control values, to varying extents. At $25^{\circ}$, in rats fed on the maize oilrich diet, falls of $1.3^{\circ}$ and $0.5^{\circ}$ were observed $1 \mathrm{~h}$ after injection of the high and low doses respectively. In rats fed on coconut oil the fall was similar in rats receiving either dose, and less severe at the higher dosage of TNF $\alpha$, than in rats fed on maize oil. Significant falls of $0.9^{\circ}$ and $0.7^{\circ}$ were observed for the high and low doses of TNF $\alpha(P<0.01$ and $P<0.01$ respectively).

An environmental temperature of $20^{\circ}$ exacerbated the fall in temperature, particularly in rats fed on maize oil and receiving the highest dosage of TNF $\alpha$. In these rats temperatures were $1.4^{\circ}, 1 \cdot 7^{\circ}$ and $0.7^{\circ}$ below starting values at $0.5,1$ and $2 \mathrm{~h}$ after injection respectively, whereas in rats at $25^{\circ}$ falls of $0.6^{\circ}, 1.3^{\circ}$ and $0.6^{\circ}$ were observed at these times. In animals given the lower dose of TNF $\alpha$, a significant fall of $0.6^{\circ}$ and $0.5^{\circ}$ become apparent $1 \mathrm{~h}$ after injection at environmental temperatures of $20^{\circ}$ and $25^{\circ}$ respectively. Although the mean 


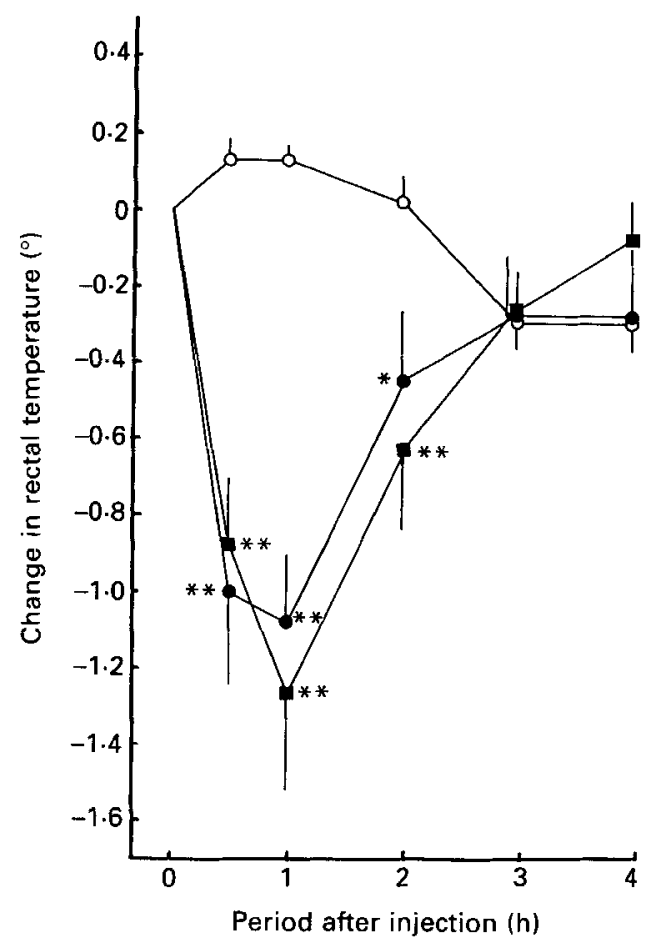

Fig. 4. Effect of intravenous injection of $30(0)$ or $300(\square) \mu \mathrm{g}$ recombinant human tumour necrosis factor $\alpha$ $(\mathrm{TNF} \alpha) / \mathrm{kg}$ body-weight, compared with sterile saline $(9 \mathrm{~g}$ sodium chloride $/ 1)(\mathrm{O})$, on rectal temperatures of rats fed from weaning for 12 weeks on a diet containing $190 \mathrm{~g}$ coconut oil and $10 \mathrm{~g}$ maize oil $/ \mathrm{kg}$. Temperatures measured at an ambient temperature of $20^{\circ}$. Values are means with their standard errors, represented by vertical bars, for groups of six rats. Values were significantly different from saline control (two-way analysis of variance): ${ }^{*} P<0.05 ;{ }^{* *} P<0.01$.

value for the temperature $0.5 \mathrm{~h}$ after injection was lower in rats at $20^{\circ}$ than $25^{\circ}$, neither value was statistically different from those of the controls. In rats fed on coconut oil a difference of only $0.9^{\circ}, 1.3^{\circ}$ and $0.6^{\circ}$ was noted following the higher dose of TNF $\alpha$ at an environmental temperature of $20^{\circ}$. As at $25^{\circ}$, raising the dose from $30 \mu \mathrm{g}$ to $300 \mu \mathrm{g} / \mathrm{kg} \mathrm{did}$ not exacerbate the hypothermia. The type of dietary fat, but not the environmental temperature, affected the speed with which rectal temperature returned towards values seen in the controls. While values had returned to normal $2 \mathrm{~h}$ after injection in rats receiving maize oil and $30 \mu \mathrm{g} \mathrm{TNF} \alpha / \mathrm{kg}$, this did not occur until $3 \mathrm{~h}$ in those fed on coconut oil. After the $300 \mu \mathrm{g} \mathrm{TNF} \alpha / \mathrm{g}$ dose, values normalized $3 \mathrm{~h}$ after injections in both dietary groups at either environmental temperature.

TNF $\alpha$ brought about changes in tissue protein and trace element content in rats from both dietary regimens. While TNF $\alpha$ had no effect on the protein content of skeletal muscle $8 \mathrm{~h}$ after injection (values not shown), tibialis protein content declined and that of liver increased $24 \mathrm{~h}$ after injection (Table 3 ). The type of diet influenced the responses of liver and tibialis muscle in that, while the lowest dose of TNF $\alpha$ produced responses in rats receiving the diet rich in maize oil, it had no significant effect in animals receiving the diet containing coconut oil. High doses of TNF $\alpha$, however, affected liver and muscle protein equally in both dietary groups. Tables 4 and 5 show serum $\mathrm{Zn}, \mathrm{Cu}$ and albumin concentrations in rats killed 8 and $24 \mathrm{~h}$ after injection. TNF $\alpha$ brought about a fall in serum $\mathrm{Zn}$ and albumin and a rise in serum $\mathrm{Cu}$. At $8 \mathrm{~h}$ after injection, serum $\mathrm{Zn}$ was significantly 


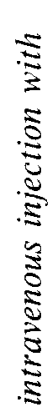

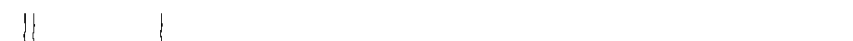

ऐ

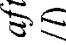

$=\frac{8}{8}$

$\stackrel{+}{2}$

$\frac{2}{5}$

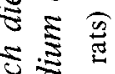

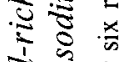

उ 00

$\exists 9$

¿

$8 \underset{0}{0}$

ᄒे

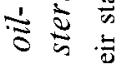

昰

ज

蛋

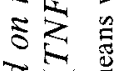

ఫ્屯

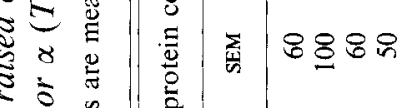

范

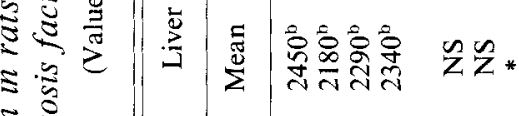

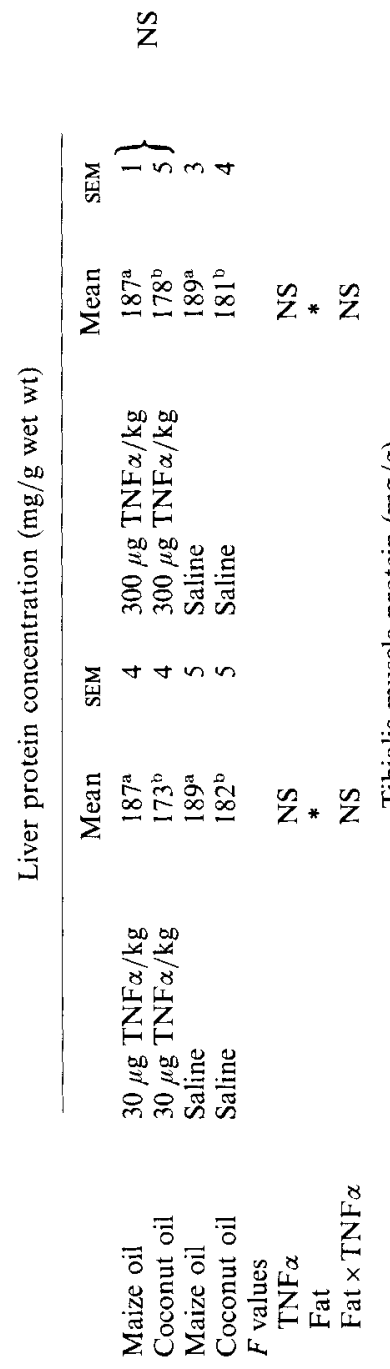

Z

$\sum_{\text {i }} \overbrace{n \rightarrow m} m$

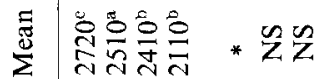

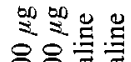

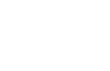

돈

词

ㅎํ

帘

$\frac{2}{3}$

$\stackrel{5}{5}$

¿

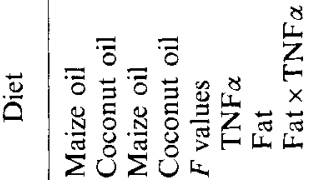

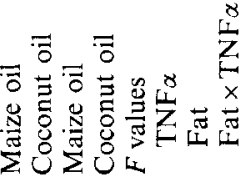

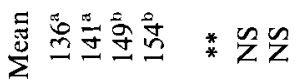

\section{की}

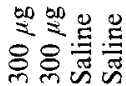

$\sum_{\text {质 }} m \infty \mathrm{m}$

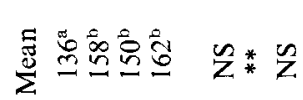

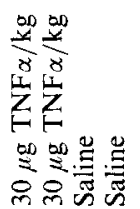

隹品

$\overline{0} \overline{0}$ 学

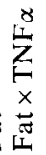

‥

过 


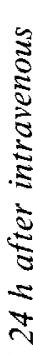

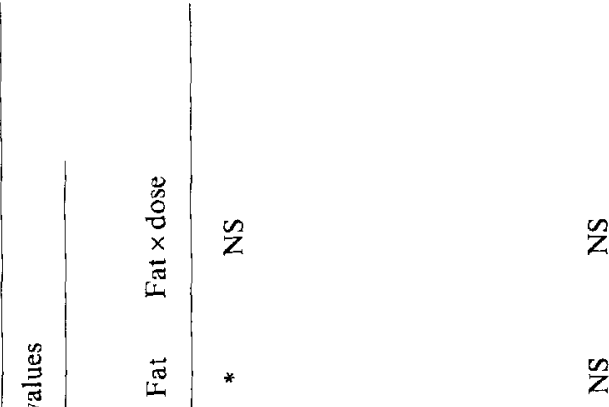

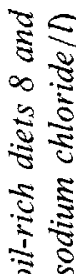

$\approx \infty \frac{\pi}{3}$

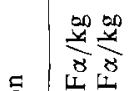

总党亖

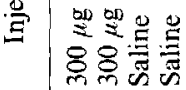

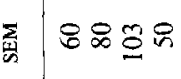

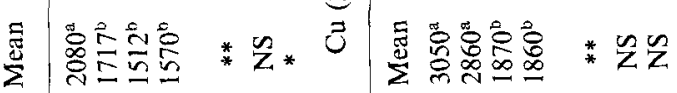

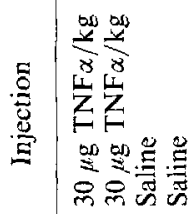

$\sum_{3}^{\infty} \frac{\infty}{x}$

Z保

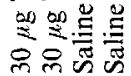

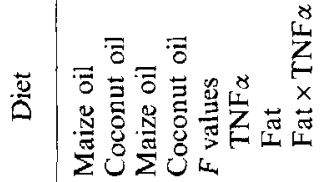




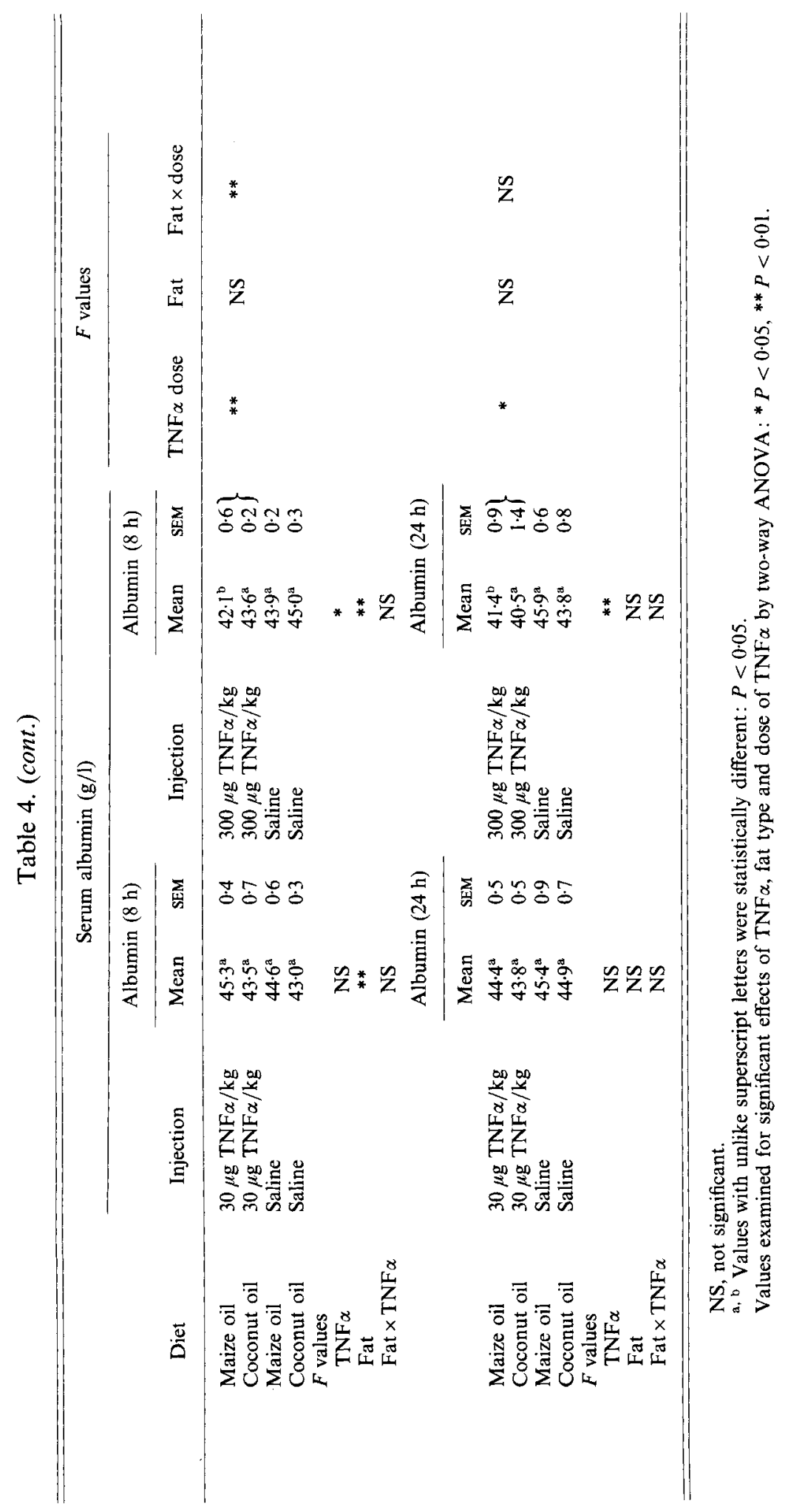




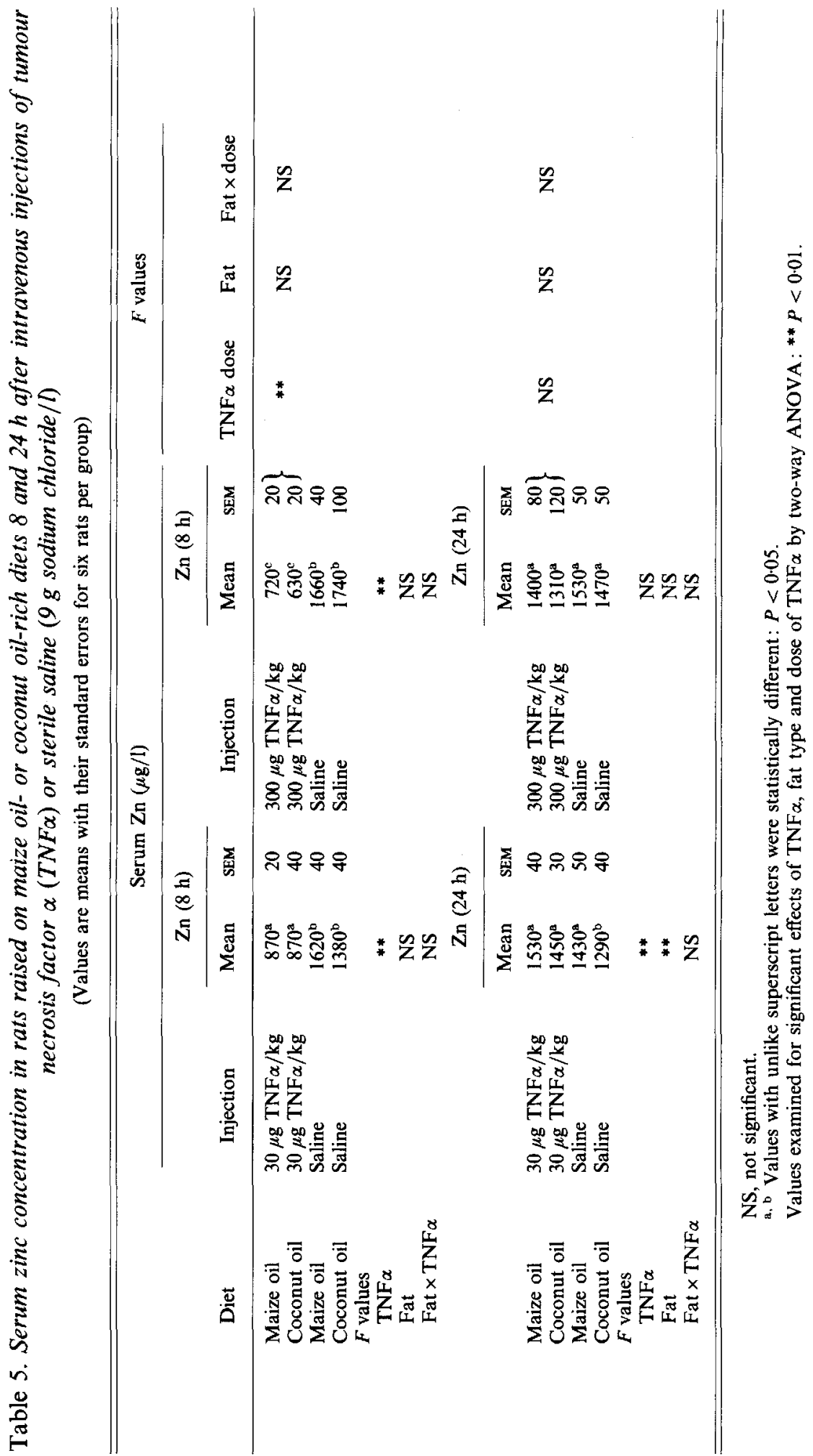




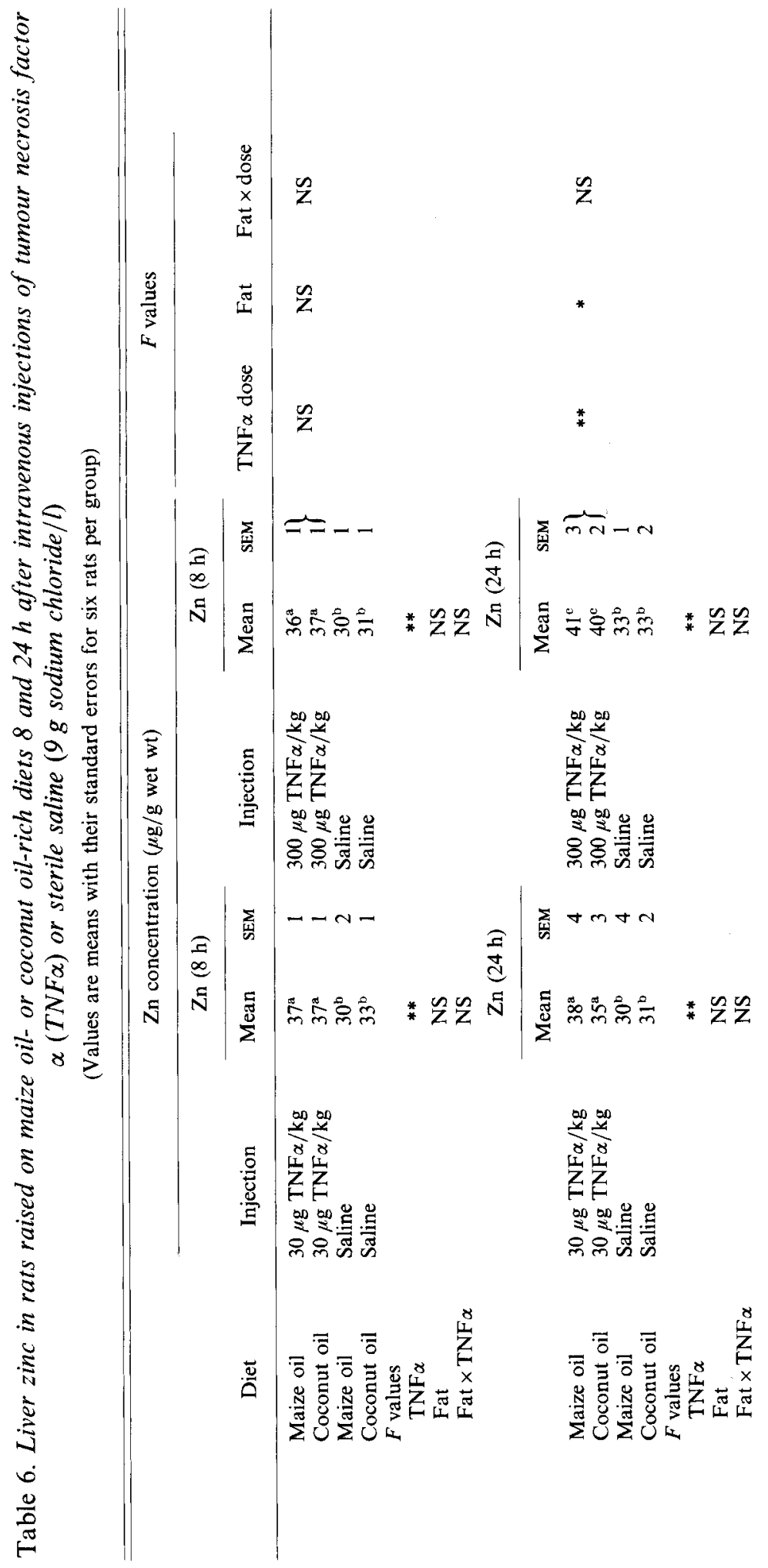




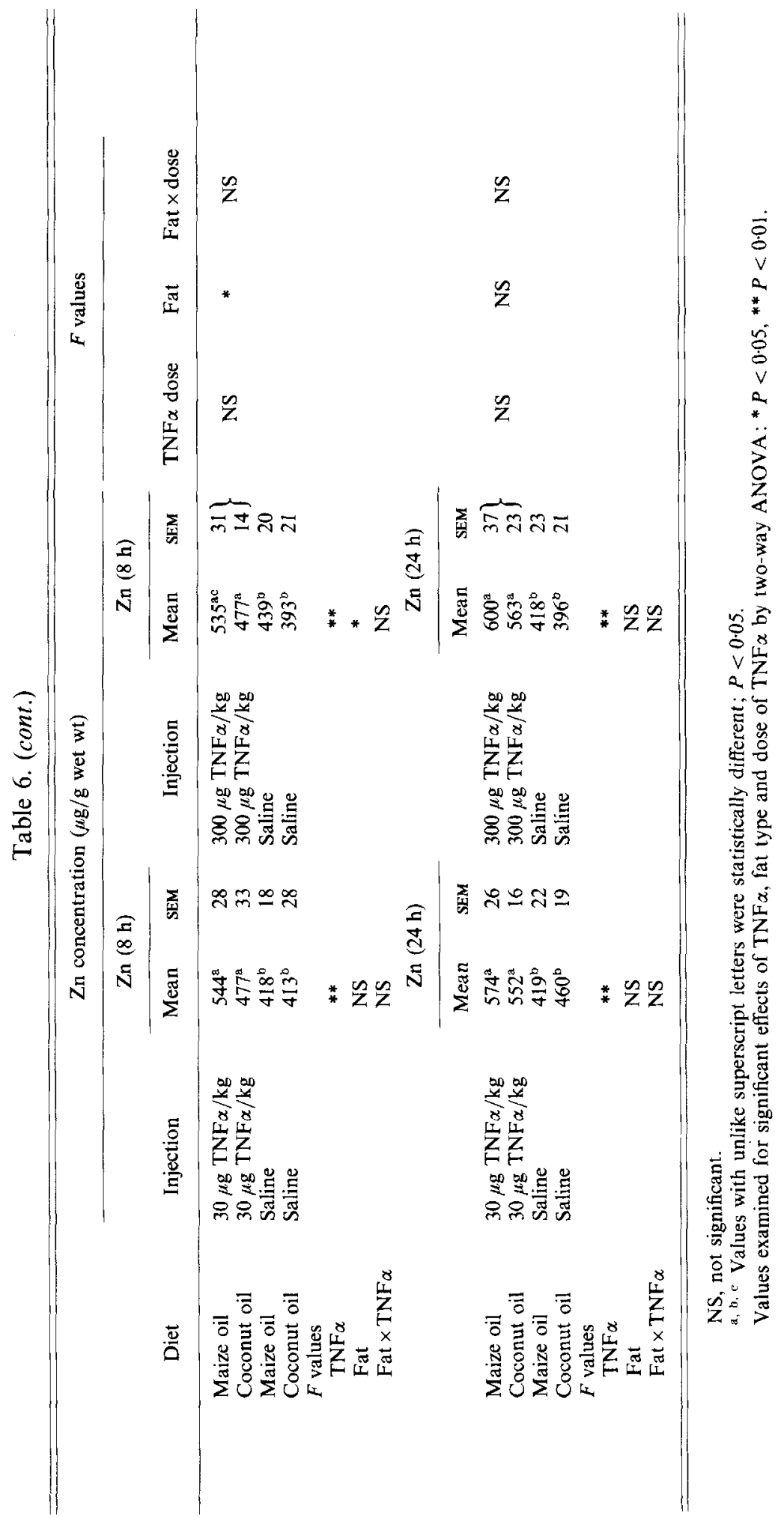


lower in rats treated with TNF $\alpha$ than in those given saline. The higher dose of TNF $\alpha$ brought about the largest fall. At $24 \mathrm{~h}$ after injection, serum $\mathrm{Zn}$ values were mostly similar to those of the pair-fed saline-injected controls. Dietary fat had no influence on the fall in serum $\mathrm{Zn}$ concentration.

Serum $\mathrm{Cu}$ was significantly elevated $24 \mathrm{~h}$ after injection of TNF $\alpha$, both doses being equally effective. The type of diet had no influence on the value achieved; however, $8 \mathrm{~h}$ after injection of the lower dose of TNF $\alpha$ an elevation occurred only in the animals fed on maize oil.

Serum albumin was reduced 8 and $24 \mathrm{~h}$ after the highest dose of TNF $\alpha$ only in rats fed on the diet rich in maize oil. In rats raised on the diet rich in coconut oil, however, the highest dose only produced a reduction in concentration at the latter time.

The concentrations and total contents of $\mathrm{Zn}$ in livers 8 and $24 \mathrm{~h}$ after injections is shown in Table 6. Values were raised at both times, in all rats injected with TNF $\alpha$. Both doses of $\mathrm{TNF} \alpha$ were equally effective, and the type of diet did not influence events.

Serum $\mathrm{Zn}$ concentration and liver $\mathrm{Zn}$ content were found to be negatively correlated, in all rats, from each dietary group, $8 \mathrm{~h}$ after injection, with $r$ values of -0.656 and -0.623 $(P<0.01, n 18)$ for rats receiving diets containing maize oil and coconut oil respectively. No relationship existed between serum $\mathrm{Zn}$ concentration and liver $\mathrm{Zn}$ content $24 \mathrm{~h}$ after injections had taken place.

\section{DISCUSSION}

The present study confirms some of the effects of TNF $\alpha$ in vivo previously reported.

Kettlehut et al. (1987) observed hypothermia in rats $1 \mathrm{~h}$ after lethal doses of TNF $\alpha$. We have observed a similar but transient hypothermia following large but sub-lethal doses of recombinant human TNF $\alpha$ (Bibby \& Grimble, 1989 ). The dose used in the present study $\left(300 \mu \mathrm{g} / \mathrm{kg}\right.$ ) represents $43 \%$ of the $\mathrm{LD}_{50}$ for human recombinant $\mathrm{TNF} \alpha$ (Tracey et al. 1986).

Our results confirm that TNF $\propto$ has complex actions on liver protein metabolism. Serum albumin concentration was depressed, serum $\mathrm{Cu}$ elevated and serum $\mathrm{Zn}$ depressed in conjunction with an increase in hepatic $\mathrm{Zn}$ content. Since serum $\mathrm{Cu}$ is indicative of the $\mathrm{Cu}-$ binding acute-phase protein caeruloplasmin, the first two changes suggest that the switch in type of hepatic protein synthesis, reported by Perlmutter et al. (1986) in vitro, also occurs in vivo. DiSilvestro \& Cousins (1985) showed that metallothionein synthesis was stimulated by IL1 and endotoxin, leading to an increase in hepatic $\mathrm{Zn}$ content and a reciprocal fall in serum $\mathrm{Zn}$ concentration. We have demonstrated that $\mathrm{TNF} \propto$ produces a similar reciprocal relationship between metallothionein and serum $\mathrm{Zn}$ content, (Grimble \& Bremner, 1989) and between hepatic $\mathrm{Zn}$ content and serum $\mathrm{Zn}$ concentration (Bibby \& Grimble, 1989b).

The results of the present study and those reported by us and other workers elsewhere suggest that $\mathrm{TNF} \alpha$, like endotoxin, can induce muscle protein loss in vivo and that a decrease in protein synthetic rate may be responsible (Jepson et al. 1986; Charters \& Grimble, 1989).

All responses to TNF $\alpha$, in the present study, showed a degree of dose dependency, with the exception of the rise in serum $\mathrm{Cu}$ and gain in liver $\mathrm{Zn}$. Coconut oil reduced the sensitivity to TNF $\alpha$ insofar as only the high dose produced a reduction in protein in muscle and a gain in the liver. Furthermore, the high dose produced a fall in serum albumin only in rats fed on maize oil. Similarly, serum $\mathrm{Cu}$ was elevated $8 \mathrm{~h}$ after TNF $\alpha$ injection in rats fed on maize oil but not in those given coconut oil. In rats given maize oil either increasing the dose of TNF $\alpha$ or reducing ambient temperature intensified the hypothermia. However, in rats receiving coconut oil, only the latter produced this phenomenon. In addition, at both environmental temperatures, the extent of the fall brought about by the highest dose of 
TNF $\alpha 1 \mathrm{~h}$ after injections was less in the rats receiving coconut oil $(P<0.05$ at both temperatures).

What mechanisms could underly the blunting actions of coconut oil? Alterations in eicosanoid production within target tissues may be partly responsible since eicosanoids are implicated in many of the actions of endotoxin or cytokines such as fever, hypothermia and muscle protein loss. However, a direct role for PGs in the stimulation of liver protein metabolism by endotoxin or pure cytokines is much less likely since the increase in liver protein content (Wan \& Grimble, 1986a) and non-secretory protein synthetic rate after endotoxin or IL1 treatment is not blocked by cyclooxygenase inhibition (Sobrado et al. 1983). Likewise cyclooxygenase inhibitors are ineffective at blocking the increase in plasma C-reactive protein (Revhaug et al. 1988) or serum amyloid P protein (Poole et al. 1984).

There is a substantial body of research which suggests that fats with low linoleate contents may alter membrane phospholipid fatty acid composition and subsequent eicosanoid production in target tissues (Croft et al. 1984).

We found that diets of the same composition as those in the present study produced substantial reductions in the arachidonic acid concentration of spleen membrane phosphatidyl choline (Wan \& Grimble, 1987). Diets containing $40 \%$ of energy in the form of coconut oil produced substantial reductions in plasma phospholipid arachidonate and linoleate. Reduced urinary excretion of 6-keto $\mathrm{PGF}_{1}$ and production of thromboxane $\mathrm{B}_{2}$ in blood occurred. Johnston \& Marshall (1984) showed that PGF $_{2 \alpha}$ and PGE $_{2}$ production were significantly reduced in liver, thymus and spleen of rats that had been fed on diets containing differing abundances of linoleate for 2 months. Membrane compositions in brain and muscle are also sensitive to change by dietary fat in the short term (Bourne et al. 1988; Jackson et al. 1988).

The observations of similarities in the blunting effects of coconut oil feeding on the actions of TNF $\alpha$ and of endotoxin (a stimulator of endogenous cytokine production) also suggest that the oil affects target-tissue sensitivity to cytokines.

The authors gratefully acknowledge the gift of recombinant human TNFa from BASF/Knoll AG, Ludwigshaven, West Germany.

\section{REFEREN CES}

American Institute of Nutrition (1977). Report of the American Institute of Nutrition ad hoc Committee on Standards for Nutritional Studies. Journal of Nutrition 107, 1340-1348.

Baracos, V., Rodemann, H. P., Dinarello, C. A. \& Goldberg, A. L. (1983). Stimulation of muscle protein degradation and prostaglandin $E$ release by leukocytic pyrogen: a mechanism for the increased degradation of muscle proteins during fever. New England Journal of Medicine 308, 553-558.

Beisel, W. T. (1975). Metabolic response to infection. Annual Reviews of Medicine 26, 9-30.

Bernheim, H. A., Block, L. H. \& Atkins, E. (1979). Fever: pathogenesis, pathophysiology, and purpose. Annals of Internal Medicine 91, 161-270.

Bibby, D. C. \& Grimble, R. F. (1989a). Leukotrienes and prostaglandins may be involved in the hypothermic effects of recombinant tumour necrosis factor $\alpha$ in rats. Proceedings of the Nutrition Society 48, $112 \mathrm{~A}$.

Bibby, D. \& Grimble, R. $(1989 \mathrm{~b})$. Temperature and metabolic changes in rats after various doses of tumour necrosis factor $\alpha$. Journal of Physiology 40, 367-380.

Bourne, J. M., Bonneil, M., Dumont, O. M., Piciotti, M., Nalbine, G. \& Lafton, H. (1988). High dietary fish oil alters the brain polyunsaturated fatty acid composition. Biochimica et Biophysica Acta 960, 458-461.

Charters, Y. \& Grimble, R. (1989). Effect of recombinant human tumour necrosis factor alpha on protein synthesis in liver, skeletal muscle and skin of rats. Biochemical Journal 358, 493-497.

Cousins, R. J. (1985). Absorption, transport, and hepatic metabolism of copper and zinc: special reference to metallothionein and ceruloplasmin. Physiological Reviews 65, 238-309.

Croft, K. D., Beilin, L. J., Vandongen, R. \& Matthews, E. (1984). Dietary modification of fatty acid and prostaglandin synthesis in the rat. Effect of variations in the level of dietary fat. Biochimica et Biophysica Acta 795, 196-207.

Dinarello, C. A. (1987). The biology of interleukin 1 and comparison to tumour necrosis factor. Immunology Letters 16, 227-232. 
Dinarello, C. A., Cannon, J. G., Mier, J. W., Bernheim, H. A., Lopreste, G., Lynn, D. L., Love, R. N., Well, A. C., Auron, P. E., Reuben, R. C., Rich, A., Wolfe, S. M. \& Putney, S. D. (1986a). Multiple biological activities of human recombinant interleukin 1. Journal of Clinical Investigation 77, 1734-1739.

Dinarello, C. A., Cannon, J. G., Wolf, S. M., Bernheim, H. A., Beutler, B., Cerami, A., Figari, I. S., Palladino, M. A. Jr. \& O'Connor, J. V. (1986b). Tumor necrosis factor (cachectin) is an endogenous pyrogen and induces production of interleukin 1. Journal of Experimental Medicine 163, 1433-1450.

DiSilvestro, R. A. \& Cousins, R. J. (1984). Mediation of endotoxin-induced changes in zinc metabolism in rats. American Journal of Physiology 247, E436-E441.

DiSilvestro, R. A. \& Cousins, R. J. (1985). Induction of rat metallothionein by interleukin 1. Journal of Leukocyte Biology 37, 697.

Endres, S., Gharbani, R., Kelley, V. E., Kostis, S., Lannemann, G., Jos, W. M., Cannon, J. G., Rogers, T. S., Klempner, M. S., Weber, P. C., Schaefer, E. J., Wolff, S. M. \& Dinarello, M. D. (1989). The effect of dietary supplementation with $n-3$ polyunsaturated fatty acids on the synthesis of interleukin- 1 and tumour necrosis factor by mononuclear cells. New England Journal of Medicine 320, 265-271.

Garlick, P. J., McNurlan, M. A. \& Preedy, V. R. (1980). A rapid and convenient technique for measuring the rate of protein synthesis in tissues by injection of $\left.{ }^{3} \mathrm{H}\right]$ phenylalanine. Biochemical Journal 192, 719-723.

Grimble, R. \& Bremner, I. (1989). Tumour necrosis factor alpha enhances hepatic metallothionein 1 content but reduces that of the kidney. Proceedings of the Nutrition Society 48,64A.

Jackson, M. J., Roberts, J. \& Edwards, R. H. T. (1988). Effects of dietary-fish-oil feeding on muscle growth and damage in the rat. British Journal of Nutrition 60, 217-224.

Jepson, M. M., Bates, P. C. \& Millward, D. J. (1986). The effects of endotoxaemia on protein metabolism in skeletal muscle and liver of fed and fasted rats. Biochemical Journal 235, 329-336.

Johnston, P. V. \& Marshall, L. A. (1984). Dietary fat, prostaglandins and the immune response. Progress in Food and Nutrition Science 8, 3-25.

Kauffman, C. A., Jones, P. G. \& Kluger, M. J. (1986). Fever and malnutrition: endogenous pyrogen/interleukin1 in malnourished patients. American Journal of Clinical Nutrition 44, 449-452.

Keenan, R. A., Moldawer, L. L., Yang, R. D., Kawamura, I., Blackburn, G. L. \& Bistrian, B. R. (1982). An altered response by peripheral leukocytes to synthesize or release leukocyte endogenous mediator in critically ill, protein-malnourished patients. Journal of Laboratory and Clinical Medicine 100, 844-857.

Kettelhut, I. C., Fiers, W. \& Goldberg, A. L. (1987). The toxic effects of tumor necrosis factor in vivo and their prevention by cyclooxygenase inhibitors. Proceedings of the National Academy of Sciences, USA 84, 42734277

Lowry, O. H., Rosebrough, N. H., Farr, A. L. \& Randall, R. J. (1951). Protein measurement with the folin phenol reagent. Journal of Biological Chemistry 219, 15I-159.

McPherson, J. B. \& Everard, B. W. (1972). Serum albumin estimation: modification of the bromocresol green method. Clinica Chimica Acta 37, 117-119.

Magrum, L. J. \& Johnston, P. V. (1985). Effect of culture in vitro with eicosatetraenoic $(20: 4(n-6))$ and eicosapentanoic $(29: 5(n-3))$ acids on fatty acid composition, prostaglandin synthesis and chemiluminescence of rat peritoneal macrophages. Biochimica et Biophysica Acta 836, 354-360.

Moncada, S. \& Vane, J. R. (1983). Essential fatty acids and their prostanoid derivatives. British Medical Bulletin 39, 209-295.

Perlmutter, D. H., Dinarello, C. A., Punsal, P. I. \& Colten, H. R. (1986). Cachectin/tumor necrosis factor regulated hepatic acute-phase gene expression. Journal of Clinical Investigation 78, 1349-1354.

Poole, S., Gordon, A. H., Baltz, M. \& Stenning, B. E. (1984). Effect of bacterial endotoxin in body temperature, plasma zinc and plasma concentration of the acute-phase protein serum amyloid P component in mice. British Journal of Experimental Pathology 65, 431-439.

Revhaug, A., Michie, R., Manson, J. M., Waters, J. M., Dinarello, C. A., Wolff, S. M. \& Wilmore, D. W. (1988). Inhibition of cyclo-oxygenase attenuates the metabolic response to endotoxin in humans. Archives of Surgery $13,162-170$.

Sobrado, J., Moldawer, L. L., Bistrain, B. R., Dinarello, C. A. \& Blackburn, G. I. (1983). Effect of Abunrofen on fever and metabolic changes induced by continuous infusion of leukocyte pyrogen (interleukin I) or endotoxin. Infection and Immunity 42, 997-1005.

Szekely, M. \& Szelenyi, Z. (1979). Endotoxin fever in the rat. Acta Physiological Academiae Scientiarum Hungaricae 53, 265-277.

Tocco-Bradley, R. \& Kluger, M. J. (1984). Zinc concentration and survival in rats infected with Salmonella typhimurium. Infection and Immunity 45, 332-338.

Tracey, K. J., Beutler, B., Lowry, S. F., Merryweather, J., Wolpe, S., Milsark, I. W., Hariri, R. J., Fahey, T. J. II, Zentalla, A., Albert, J. D., Shires, G. T. \& Cerami, A. (1986). Shock and tissue injury induced by recombinant human cachectin. Science 234, 470-474.

Wan, J. \& Grimble, R. F. (1986a). Inhibitory effects of indomethacin on some features of the metabolic response to Escherichia coli endotoxin in rats. Proceedings of the Nutrition Society 45, 51A.

Wan, J. \& Grimble, R. F. (1986 b). Effect of a lipoxygenase inhibitor, AA861, on the metabolic response to Escherichia coli endotoxin in rats. Proceedings of the Nutrition Society 45, 38A.

Wan, J. \& Grimble, R. F. (1987). Effect of dietary linoleate content on the metabolic response of rats to Escherichia coli endotoxin. Clinical Science 72, 383-385. 